\title{
In Vitro Antioxidant Activity of Aqueous Extracts from the Atemoya Fruit (Peel, Pulp, and Seed): Correlation of Their Protein, Carbohydrate, and Phenolic Compound Contents
}

\author{
Serquiz $\mathrm{AC}^{* 1}$, Alves $\mathrm{MGCF}^{2}$, Fernandes-Negreiros $\mathrm{MM}^{3}$ and Rocha $\mathrm{HAO}^{4}$
}

${ }^{1}$ Programa de Pós Graduação em Ciências da Saúde da Universidade Federal do Rio Grande do Norte- CCS, Laboratório de Biotecnologia de Polímeros Naturais (BIOPOL), Departamento de Bioquímica, Centro de Biociência, Universidade Federal do Rio Grande do Norte (UFRN), Natal, Rio Grande do Norte, RN, Brazil

${ }^{2}$ Laboratório de Biotecnologia de Polímeros Naturais (BIOPOL), Departamento de Bioquímica, Centro de Biociência, Universidade Federal do Rio Grande do Norte (UFRN), Natal, Rio Grande do Norte, RN, Brazil

${ }^{3}$ Laboratório de Biotecnologia de Polímeros Naturais (BIOPOL), Departamento de Bioquímica, Centro de Biociência, Universidade Federal do Rio Grande do Norte (UFRN), Natal, Rio Grande do Norte, RN, Brazil

${ }^{4}$ Programa de Pós Graduação em Ciências da Saúde da Universidade Federal do Rio Grande do Norte -CCS, Laboratório de Biotecnologia de Polímeros Naturais (BIOPOL), Departamento de Bioquímica, Centro de Biociência, Universidade Federal do Rio Grande do Norte (UFRN), Natal, Rio Grande do Norte, RN, Brazil

*Corresponding author: Serquiz AC, Programa de Pós Graduação em Ciências da Saúde da Universidade Federal do Rio Grande do Norte-CCS, Laboratório de Biotecnologia de Polímeros Naturais (BIOPOL), Departamento de Bioquímica, Centro de Biociência, Universidade Federal do Rio Grande do Norte (UFRN), Natal, Rio Grande do Norte, RN, Brazil, Tel: +55-84-3215-3416, E-mail: alexandreserquiz@gmail.com

Citation: Serquiz AC, Alves MGCF, Fernandes-Negreiros MM, Rocha HAO (2018) In Vitro Antioxidant Activity of Aqueous Extracts from the Atemoya Fruit (Peel, Pulp, and Seed): Correlation of Their Protein, Carbohydrate, and Phenolic Compound Contents. J Adv Food Technol 1(1): 103. doi: 10.15744/2639-

3328.1 .103

Received Date: June 28, 2018 Accepted Date: July 24, 2018 Published Date: July 27, 2018

\begin{abstract}
The properties of several fruits still remain unevaluated, with regard to being the source of antioxidant compounds, one of such fruits being atemoya. In this study, three parts (seed, pulp, and peel) of atemoya were submitted to extraction. Five water volume ratios $(1: 1,1: 2,1: 4,1: 8$, and 1:10) were used in relation to the same material mass rendered, thus, five extracts from each part. The protein, carbohydrate, and phenolic compound contents of these extracts varied according to the volume applied, which affected the activity of the extracts. The pulp extracts exhibited the best superoxide and hydroxyl radical-scavenging activities, whereas the peel extracts yielded the best iron-chelating activity. Nevertheless, the 1:1 seed, 1:1 pulp, and 1:10 peel extracts yielded an overall best antioxidant activity. Correlation studies identified protein components as the primary metabolites influencing the antioxidant activity of the extracts. This study provided experimental evidence that atemoya (peel, seed, and pulp) can be a powerful source of antioxidant metabolites. However, further in vivo studies must be performed to verify the potential of atemoya.
\end{abstract}

Keywords: Antioxidant Proteins; Radical Scavenging; Iron Chelator; Tropical Fruits; Annona sp.

\section{Introduction}

According to the National Academy of Sciences, a "food antioxidant is any substance in the diet capable of significantly reducing the adverse effects produced by reactive species such as those of oxygen and nitrogen." [1]. The term antioxidant activity refers to the ability of a bioactive compound to maintain the structure and function of cells by neutralizing free radicals and reactive species, inhibiting, for instance, lipid peroxidation reactions [2].

Oxidative stress is a serious imbalance that occurs when the quantity of reactive species exceeds the antioxidant neutralization capability of the defense system in an organism. The most common forms of reactive species include the superoxide radical, hydrogen peroxide, hydroxyl radical, and nitric oxide. These forms have high in vivo and in vitro biological activity, which may directly result in DNA mutation, gene expression alteration, signal transduction, cellular apoptosis, lipid peroxidation, and protein 
degradation [3]. The prevention and treatment of some chronic and degenerative diseases involve the elimination of reactive oxygen species (ROS) to reduce the oxidative stress of the body. Since natural antioxidants such as those present in fruits and vegetables have the ability to reduce the oxidative stress produced by free radicals and the subsequent cellular damages, they have been associated with several types of treatment strategies against chronic diseases [3,4]. The World Health Organization has been increasingly encouraging the consumption of fruits, and the resulting benefits justify the increasing world consumption [5]. In addition, traditionally discarded fruit residues are currently being recognized as a valuable substrate for obtaining nutrients and/ or phytochemicals [6-8]. The Annonaceae family comprises a large number of genera and plant species, the majority of which are native to the tropics. This family includes about 2,500 species distributed in approximately 135 genera [9]. The atemoya fruit is a hybrid derived from the cross between a tropical fruit, the sweetsop (Annona squamosa L.), and cherimoya (A. cherimola Mill.), native to the Andean regions of Chile, Peru, Bolivia, and Ecuador. Nevertheless, there is limited information regarding the antioxidant capability of atemoya and its parts. Therefore, to add more information in this context, this study was conducted to evaluate the antioxidant capacity of the aqueous extracts of the seed, peel, and pulp of the atemoya fruit. This study also determined the correlation between the antioxidant ability and the phenolic, protein, and glucose components found in these extracts.

\section{Experimental}

\section{The Atemoya Fruit}

Atemoya fruit samples (A. cherimola Mill. $\times$ A. squamosa L.) were obtained from supermarkets in the city of Natal-RN in February 2014.

\section{Preparation of Seed, Peel, and Pulp Extracts}

Cleaning and sterilization of the fruits were performed with the intact peel by washing in running water and subsequent immersion in chlorinated water $(250 \mathrm{ppm})$ for $15 \mathrm{~min}$. The fruits were washed again in running drinking water for disposing chlorine residues, compliant to the current regulations of the health surveillance legislation in Brazil [10].

After sterilization, the fruit was peeled and its seeds, peel, and pulp were manually extracted and separated and then separately stored in $50-\mathrm{mL}$ conical bottom tubes at $-80{ }^{\circ} \mathrm{C}$ until the preparation of the extracts. For the preparation of aqueous extracts, the three parts (peel, seed, and pulp) were individually weighed and then diluted in distilled water at five different ratios, 1:1, 1:2, 1:4, $1: 8$, and 1:10 ( $\mathrm{g}$ of fruit extract/mL of distilled water).

Following the dilution, the extracts were triturated for $3 \mathrm{~min}$ at $4{ }^{\circ} \mathrm{C}$ and then homogenized for $2 \mathrm{~h}$ on a magnetic stirrer. Then, the diluted peel, pulp, and seed extracts were individually centrifuged at 7,500 $\times \mathrm{g}$ for $30 \mathrm{~min}$ at $4{ }^{\circ} \mathrm{C}$ and filtered through a filter paper and funnel. After filtration, the extracts were lyophilized, which resulted in 15 samples relative to the three different parts of the fruit and the five aforementioned solute: solvent ratios.

\section{Evaluation of the Total Phenolic Compounds, Proteins, and Carbohydrates}

Total phenolic compounds assessment - the total phenolic content was measured in triplicate, and the tests were repeated three times for each extract as described by (2014) [11]. An analytical curve containing 500, 400, 300, 200, 100, 50, 10 and $0 \mathrm{mg} / \mathrm{ml}$ of gallic acid was used as an equivalence reference. $200 \mu \mathrm{l}$ of extracts was then separately added to the test tubes, then $1400 \mu \mathrm{l}$ of ultrapure water, and $100 \mu \mathrm{l}$ of Folin reagent. The tubes were then shaken in a tube shaker and rested for ten minutes at room temperature. Sequentially, $50 \mu \mathrm{l}$ of $20 \%$ sodium bicarbonate was added to the tubes, which were again stirred and placed in a water bath at $40{ }^{\circ} \mathrm{C}$ for 20 minutes. Whites containing only the respective extraction buffers from each extract were made to exclude residual absorbance. The absorbance readings were performed at $765 \mathrm{~nm}$ in a spectrophotometer. Protein Dosage-all protein determinations were performed by the method of with modifications [12]. In a 96-well flat bottom plate, $10 \mu \mathrm{L}$ of the extracts was placed in different titrations. Subsequently, $200 \mu \mathrm{l}$ of the Bradford reagent was added and the plate was rested for approximately ten minutes before being read on a microplate reader at $595 \mathrm{~nm}$. Bovine albumin was used to determine the standard curve and wells containing only $10 \mu \mathrm{L}$ of the extraction buffers were used as white.

The total carbohydrate content was determined following the Dubois method, and, as a comparative standard, a curve containing different D-glucose titrations was prepared [13]. In all tests, tubes containing only the extraction plugs were used as a white parameter, and the tests were performed three times in triplicate.

\section{Antioxidant Activity}

The antioxidant activities were evaluated using the following four different types of in vitro tests: total antioxidant capacity (TAC), ion chelation $(\mathrm{Fe})$, scavenging of hydroxyl radicals, and superoxide radicals. In all four tests, the samples were used at the initial concentration of $10 \mathrm{mg} / \mathrm{mL}$. The tests were performed at three different time points (independent tests) and in triplicate as described earlier [14]. 


\section{Total Antioxidant Capacity}

The principle of this test involves the reduction of Molybdenum ${ }^{+6}$ to Molybdenum ${ }^{+5}$, with the formation of the green complex phosphate/Molybdenum ${ }^{+5}$ in acidic $\mathrm{pH}$. Aqueous extracts of the atemoya fruit and the reagent solutions (0.6 M sulfuric acid, $28 \mathrm{mM}$ sodium phosphate, and $4 \mathrm{mM}$ ammonium molybdate) were incubated at $95{ }^{\circ} \mathrm{C}$ for $90 \mathrm{~min}$. After this incubation, the absorbent capacities of each extract were measured at $695 \mathrm{~nm}$ against white. The TAC was expressed as ascorbic acid equivalent/ gram of atemoya extract.

\section{Hydroxyl Radical-Scavenging Activity}

The hydroxyl radical-scavenging activity of the extracts was evaluated based on Fenton reactions. The radicals were generated by mixing several solutions as follows: a $150 \mathrm{mM}$ sodium phosphate buffer ( $\mathrm{pH} 7.4$ ) mixed with $10 \mathrm{mM}$ ferrous sulfate heptahydrate, $10 \mathrm{mM}$ ethylenediaminetetraacetic acid (EDTA), $2 \mathrm{mM}$ sodium salicylate, and $30 \%$ hydrogen peroxide. For the control sample (white), the hydrogen peroxide was replaced with the phosphate buffer. The samples with a concentration of $10 \mathrm{mg} / \mathrm{mL}$ were incubated in a water bath at $37^{\circ} \mathrm{C}$ for $1 \mathrm{~h}$, and the radical-scavenging capacity was detected by analyzing the absorption capacity of each solution at $510 \mathrm{~nm}$. Gallic acid was used as a positive control. The results were expressed as the percentage of hydroxyl radical inhibition.

\section{Superoxide Radical-Scavenging Activity}

The evaluation of superoxide radical-scavenging activity was based on the photochemical inhibition of nitro blue tetrazolium chloride (NBT) in the riboflavin-light-NBT system. Extracts of $10 \mathrm{mg} / \mathrm{mL}$ sample were added to a solution of $50 \mathrm{mM}$ phosphate buffer (pH 7.8), 2 mM riboflavin, $100 \mathrm{mM}$ EDTA, $13 \mathrm{mM} \mathrm{L-methionine,} \mathrm{and} 75 \mathrm{mM}$ NBT. All reagents were mixed, enclosed in a vessel, and illuminated with a fluorescent light for $10 \mathrm{~min}$. The production of formazan blue was monitored by increasing the absorbance at $580 \mathrm{~nm}$ after the test time. Gallic acid was used as a positive control. The results were expressed as the scavenging percentage of superoxide radicals.

\section{Iron Chelation Test}

This test was performed to measure the iron-chelating ability of the fruit extracts. Briefly, $2 \mathrm{mM}$ ferrous chloride and $5 \mathrm{mM}$ ferrozine were mixed with $10 \mathrm{mg} / \mathrm{mL}$ atemoya extracts and incubated for $10 \mathrm{~min}$ at $25^{\circ} \mathrm{C}$. The color change was measured by the absorbance value on a microplate reader (Biotek, Winooski, VT, USA) at $562 \mathrm{~nm}$ against a white sample. EDTA was used as a positive control. The ability of the samples to chelate the iron ions was calculated using the following equation: [(white absorbanceazole extract absorbance / white absorbance) $] \times 100$.

\section{Statistical Analysis}

The results were expressed as mean \pm standard deviation. Two-way ANOVA was used to test the differences between the samples, as well as between different treatments of the same sample. The Tukey test was applied to verify the similarities evaluated using the ANOVA test. The Pearson's correlation test was performed between the variables to evaluate the existing correlations. All statistical analyses were considered as significant when the $\mathrm{p}$ value was $<5 \%$ or $<0.05$. All the data were stored and statistically analyzed in the GraphPad Prism software, version 7.0, La Jolla, California, USA, 2016.

\section{Results and Discussion}

\section{Yields under Different Extraction Conditions}

After the preparation as described in the methods, the fruit was opened and separated into the three parts, namely, pulp, seed, and peel. Table 1 shows the weight $(\mathrm{g})$ of each of these parts and their percentage with reference to the total weight of the material. The pulp corresponds to more than half of the fruit weight $(\sim 59 \%)$. However, about $40 \%$ of the fruit's weight is composed of material that is traditionally wasted, i.e., seed $(\sim 12 \%)$ and peel $(\sim 28 \%)$. It has been reported that of the approximately $4,000,000$ tons of atemoya produced in the world, 10 tons of waste (seed and peel) are presumably discarded [15]. This waste could be used for biotechnological and even pharmacological purposes.

\begin{tabular}{|c|c|c|}
\hline Atemoya Part & Fruit Part Mass (g) & (\%) \\
\hline Peel & $333,3 \pm 26,6$ & $28 \pm 2,5$ \\
\hline Pulp & $705,0 \pm 45,9$ & $59,2 \pm 2,8$ \\
\hline Seed & $152,8 \pm 11,2$ & $12,8 \pm 1,4$ \\
\hline Total & $1.191,1$ & 100 \\
\hline
\end{tabular}

Table 1: Weight of the atemoya fractions and respective ratios

${ }^{\star}$ The data correspond to the average \pm standard deviation $(n=3)$. 
The aqueous extracts of the atemoya fruit parts were obtained as described in the methods. It is worth mentioning that water is selected as the solvent for food preparation in homes all over the world. Table 2 shows the amount of material obtained under the different extraction conditions. Regarding the seed, it can be observed that the amount of extracted material varied between 4.3 and $6.9 \mathrm{~g}$. It can also be observed that the higher the amount of solvent, the more was the material obtained. This trend did not repeat for the remaining fruit sources. In particular, the amount of material (dry weight) obtained was always very similar, varying from 2.1 to $2.9 \mathrm{~g}$ for the pulp and from 7.4 to $7.8 \mathrm{~g}$ for the peel. This implies that, on an average, three times as much material was obtained from the peel compared to that from the pulp. The peel corresponds to about $28 \%$ of the weight of the fruit, whereas the pulp equals to $59 \%$, i.e., only twice as much, which implies that as a source of extract, and containing possible bioactive molecules, the peel is much more promising than the pulp. However, the former is wasted.

\begin{tabular}{|c|c|c|c|c|c|c|}
\hline Dilution $(\mathbf{g} / \mathbf{m L})$ & Pulp Volume $(\mathbf{m L})$ & Dry Weight $(\mathbf{g})$ & Peel Volume $(\mathbf{m L})$ & Dry Weight $(\mathbf{g})$ & Seed Volume $(\mathbf{m L})$ & Dry Weight $(\mathbf{g})$ \\
\hline $1: 1$ & 22 & 2,6 & 17 & 7,8 & 7 \\
\hline $1: 2$ & 60 & 2,1 & 41 & 7,4 & 34 \\
\hline $1: 4$ & 116 & 2,8 & 88 & 7,5 & 92 \\
\hline $1: 8$ & 198 & 2,1 & 163 & 7,8 & 214 \\
\hline $1: 10$ & 304 & 2,9 & 258 & 7,4 & 5,3 \\
\hline
\end{tabular}

Table 2: Amount of material obtained under each extraction condition

The choice for these different water volumes to obtain the extracts was based on the fact that for the fruit juices prepared in most of the households in the world, the ratio of fruit to water is around 1:8 [16]. The smaller water volumes were used to verify to which proportion of water the bioactive agents could no longer be extracted.

\section{Quantification of Proteins, Carbohydrates, and Phenolic Compounds in the Atemoya Fruit Extracts}

The aqueous extracts were quantified in terms of protein, carbohydrate, and phenolic compound contents. These data are summarized in Table 3. Regarding the amount of phenolic compounds, regardless of the extraction condition and the source used, only low levels of these molecules were always obtained when compared, for instance, with the amount of strawberry phenolic compounds extracted with water dilution $(3.6 \mathrm{mg} / \mathrm{g}$ fruit) [16]. This low amount of phenolic compounds can also be attributed to the use of water as the solvent, as it has been reported that the use of alcohols (methanol or ethanol) was more efficient in the extraction of phenolic compounds [17].

\begin{tabular}{|c|c|c|c|}
\hline \multicolumn{3}{|c|}{ Seed } \\
\hline & Protein $(\mu \mathrm{g} / \mu \mathrm{L})$ & Carbohydrates $(\mu \mathrm{g} / \mu \mathrm{L})$ & Phenolic compounds $(\mu \mathrm{g} / \mu \mathrm{L})$ \\
\hline $1: 1$ & $19,95 \pm 1,69^{\mathrm{a}}$ & $0,290 \pm 0,01^{\mathrm{a}}$ & $0,152 \pm 0,021^{\mathrm{a}}$ \\
\hline $1: 2$ & $13,70 \pm 0,72^{\mathrm{b}}$ & $0,409 \pm 0,03^{\mathrm{b}}$ & $0,126 \pm 0,018^{\mathrm{a}}$ \\
\hline $1: 4$ & $14,40 \pm 0,41^{\mathrm{b}}$ & $0,233 \pm 0,02^{\mathrm{c}}$ & $0,456 \pm 0,011^{\mathrm{b}}$ \\
\hline $1: 8$ & $9,582 \pm 0,13^{\mathrm{c}}$ & $1,168 \pm 0,03^{\mathrm{d}}$ & $0,030 \pm 0,010^{\mathrm{a}}$ \\
\hline $1: 10$ & $13,70 \pm 0,72^{\mathrm{b}}$ & $0,409 \pm 0,03^{\mathrm{b}}$ & $0,049 \pm 0,010^{\mathrm{a}}$ \\
\hline$p$ & $<0,001$ & $<0,001$ & $<0,001$ \\
\hline \multicolumn{5}{|c|}{ Pulp } \\
\hline $1: 1$ & $0,21 \pm 0,01^{\mathrm{a}}$ & $0,510 \pm 0,08^{\mathrm{a}}$ & $0,173 \pm 0,014^{\mathrm{a}}$ \\
\hline $1: 2$ & $0,13 \pm 0,01^{\mathrm{b}}$ & $0,400 \pm 0,05^{\mathrm{a}, \mathrm{b}}$ & $0,125 \pm 0,013^{\mathrm{b}}$ \\
\hline $1: 4$ & $0,12 \pm 0,004^{\mathrm{c}, \mathrm{b}}$ & $0,302 \pm 0,03^{\mathrm{b}}$ & $0,088 \pm 0,011^{\mathrm{c}}$ \\
\hline $1: 8$ & $0,12 \pm 0,005^{\mathrm{d}, \mathrm{b}}$ & $1,145 \pm 0,04^{\mathrm{c}}$ & $0,068 \pm 0,010^{\mathrm{d}}$ \\
\hline $1: 10$ & $0,12 \pm 0,005^{\mathrm{e}} \mathrm{b}$ & $1,542 \pm 0,91^{\mathrm{d}}$ & $0,059 \pm 0,013^{\mathrm{e}}$ \\
\hline$p$ & $<0,001$ & $<0,001$ & $<0,001$ \\
\hline \multicolumn{5}{|c|}{ Peel } \\
\hline $1: 1$ & $0,520 \pm 0,01^{\mathrm{a}}$ & $1,642 \pm 0,04^{\mathrm{a}}$ & $0,291 \pm 0,090^{\mathrm{a}}$ \\
\hline $1: 2$ & $0,429 \pm 0,02^{\mathrm{b}}$ & $1,663 \pm 0,03^{\mathrm{a}, \mathrm{b}}$ & $0,991 \pm 0,079^{\mathrm{b}}$ \\
\hline $1: 4$ & $0,414 \pm 0,01^{\mathrm{c}, \mathrm{b}}$ & $1,733 \pm 0,07^{\mathrm{b}}$ & $0,667 \pm 0,071^{\mathrm{c}}$ \\
\hline $1: 8$ & $0,428 \pm 0,02^{\mathrm{d}, \mathrm{b}}$ & $0,940 \pm 0,90^{\mathrm{c}}$ & $0,471 \pm 0,024^{\mathrm{d}}$ \\
\hline $1: 10$ & $0,355 \pm 0,05^{\mathrm{e}}$ & $1,600 \pm 0,06^{\mathrm{a}}$ & $0,296 \pm 0,014^{\mathrm{a}}$ \\
\hline$p$ & $<0,001$ & $<0,001$ & $<0,001$ \\
\hline
\end{tabular}

Table 3: Amount of protein, carbohydrates, and phenolic compounds in the peel, pulp, and seed extracts at the concentrations of $1: 1,1: 2,1: 4,1: 8$, and $1: 10$

*The data correspond to the average \pm standard deviation $(n=3)$. Values marked with the same letter along the same column for each extract do not present significant difference from one another $(\mathrm{p}>0.05)$ 
Regarding the carbohydrate content, the peel was the primary source for these molecules. Furthermore, it was found that regardless of the amount of solvent, the amount of extracted sugar was similar in the different peel extracts, except for the 1:8 samples (Table 3). In the pulp and seed extracts, the highest amounts of sugars were observed when a greater amount of solvent was used.

Concerning the amount of proteins, it was observed that regardless of the relationship between mass and solvent volume, the seed extracts showed the highest amount of protein. However, this extraction in greater quantity was not proportional to the amount of solvent used.

\section{In Vitro Evaluation of the Antioxidant Potential of the Different Extracts Obtained from the Atemoya Fruit Evaluation of TAC of the Atemoya Fruit Extracts}

Initially, the extracts (peel, pulp, and seed) were evaluated for their TAC. This test enables evaluation of the ability of the samples to donate electrons in a low-acid environment and, therefore, infers whether they are capable of neutralizing reactive species such as oxygen. The results are summarized in Table 4.

\begin{tabular}{|c|c|c|c|c|c|c|}
\hline \multirow{2}{*}{ Fruit Parts } & \multicolumn{7}{|c|}{ Extracts } \\
\cline { 2 - 7 } & $1: 1$ & $1: 2$ & $1: 4$ & $1: 8$ & $1: 10$ & $\mathrm{p}$ \\
\hline Seed & $94,25^{\mathrm{a}}( \pm 3,83)$ & $77,59^{\mathrm{b}, \mathrm{e}}( \pm 1,74)$ & $85,92^{\mathrm{c}}( \pm 3,53)$ & $51,03^{\mathrm{d}}( \pm 0,76)$ & $77,59^{\mathrm{e}}( \pm 1,74)$ & $\mathrm{P}<0,001$ \\
\hline Peel & $164,10^{\mathrm{f}}( \pm 2,23)$ & $106,8^{\mathrm{c}, \mathrm{g}}( \pm 1,25)$ & $73,75^{\mathrm{e}, \mathrm{h}}( \pm 2,63)$ & $98,33^{\mathrm{a}, \mathrm{i}}( \pm 1,98)$ & $64,89^{\mathrm{j}}( \pm 1,66)$ & $\mathrm{P}<0,001$ \\
\hline Pulp & $197,30^{\mathrm{l}}( \pm 1,16)$ & $38,08^{\mathrm{n}, \mathrm{m}}( \pm 1,02)$ & $34,10^{\mathrm{n}}( \pm 0,36)$ & $156,90^{\circ}( \pm 0,69)$ & $138,60^{\mathrm{p}}( \pm 2,35)$ & $\mathrm{P}<0,001$ \\
\hline
\end{tabular}

It was observed that the TAC values did not vary proportionally to the volume of solvent used. However, unlike the observations obtained for the dry weight and the amount of food antioxidants (proteins, carbohydrates, and phenolic compounds), it is obvious that the values showed wide variations, indicating that the use of different volumes of solvents affected the quality of the food antioxidants extracted and the amount of a specific food antioxidant. To our knowledge, there is no report of any study using similar analyses. However, a recent study evaluating the TAC of kelp extract reported similar results as those presented herein, i.e., the use of different volumes of solvent resulted in extracts with different TAC values, and there was a positive correlation between the sulfation degree of the carbohydrates in the sample and the TAC, but not the volume of solvent used [18].

When the TAC rates were compared between the extracts, it was observed that the highest values were found for the 1:1 pulp extract, 1:1 peel extract, and 1:8 pulp extract. The values were similar to those observed for other fruits, as shown in the study by, who reported a TAC value of 155.46 AAE for a mixture of acerola, cashew, and açaí. These values were superior to those reported for other tropical fruits such as siriguela (Spondias purpurea), mangaba (Harconia speciosa), sapoti (Manikara sapota), starfruit (Averrhoa carambola), and hog plum (S. lutea), the extracts of all of which did not exhibit TAC values $>35$ AAE [19,20].

\section{Evaluation of Superoxide Radical-Scavenging Activity of Atemoya Fruit Extracts}

The superoxide radical is a highly toxic species produced by numerous biological and photochemical reactions. This radical is a type of reactive oxygen that may cause damage to several molecules, including proteins, lipids, and DNA, leading to cellular and tissue damage and several diseases [21]. It is known to be produced in vivo and lead to $\mathrm{H}_{2} \mathrm{O}_{2}$ formation via dismutation reaction, which is another highly damaging oxidizing agent to cells [22]. Therefore, it is important to identify extracts with superoxide ionscavenging activity. Of all the seed extracts, the activity was identified only for the 1:10 extract, which showed values of $27.83 \% \pm$ $7.76 \%, 36.00 \% \pm 10.37 \%$, and $36.33 \% \pm 8.76 \%$ at the respective tested concentrations of $0.05,0.25$, and $0.50 \mathrm{mg} / \mathrm{mL}$. There $\mathrm{might}$ be other classes of molecules that have not been evaluated, which have low water solubility, and, therefore, were extracted only using larger volumes of water, but still possessing superoxide radical-scavenging activity. Consistent with this hypothesis, reported that fatty acids, carotenoids, tocopherols, and tocotrienols (molecules that are poorly soluble in water) were responsible for the superoxide radical-scavenging capacity of extracts [23]. Future studies could assess such other classes of molecules in the seed extract that have superoxide radical-scavenging capacity. The results obtained using the peel and pulp extracts are shown in Figure 1. It was observed that the amount of scavenging agents extracted from the two fruit sources was proportional to the increase in the solvent volume used, i.e., the more the solvent, the more the amount of scavenging agents extracted and, thus, the higher the activity observed. In all cases, the highest scavenging activity was about 70\%, with the pulp extracts exhibiting the maximum activity. For instance, considering the 1:1 ratio of peel and pulp extracts, the pulp extract showed a scavenging activity of about $70 \%$ (at $0.5 \mathrm{mg} / \mathrm{mL}$ ), whereas the scavenging activity of the peel extract did not reach this level at the same concentration.

evaluated only the EC50 value of the pulp extracts of Eugenia brasiliensis $(2.15 \mathrm{mg} / \mathrm{mL})$, E. myrcianthes (4.02 mg/mL), and E. leitonii $(2.67 \mathrm{mg} / \mathrm{mL})$ and found that, in all cases, a much higher concentration was required than that used for the atemoya pulp extracts [24]. Another study evaluated three extracts of Syzygium densiflorum and reported a superoxide radical-scavenging activity of about $80 \%$ at a concentration of $0.5 \mathrm{mg} / \mathrm{mL}$. However, these extracts were obtained using ethanol, ethyl acetate, and hexane, which are toxic to humans and the environment [25]. 
a)

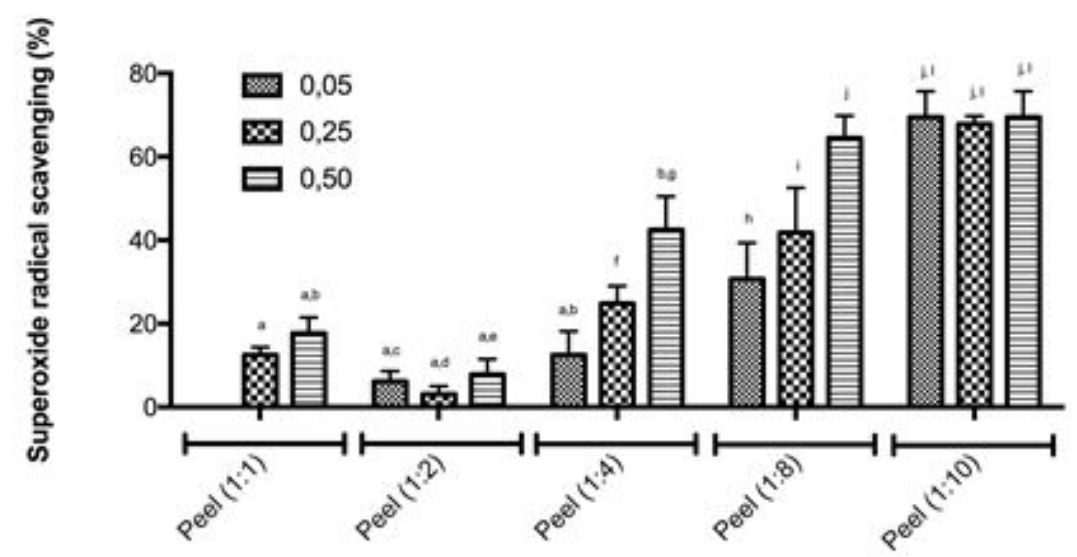

b)

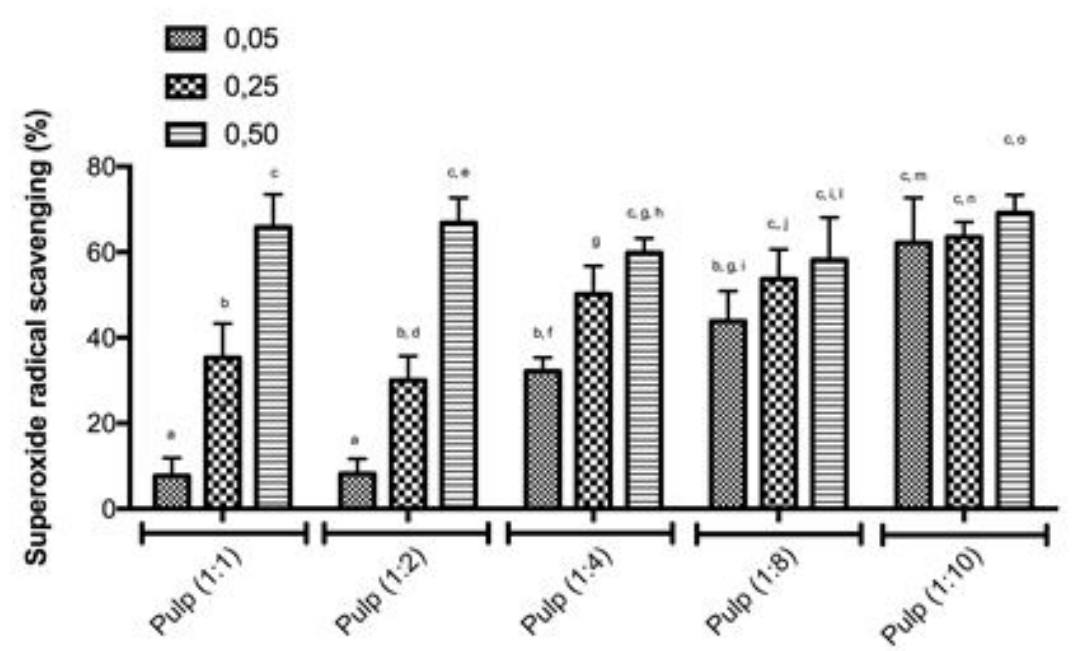

Figure 1: Evaluation of the superoxide radical-scavenging activity of the atemoya extracts. The concentrations were of $0.05,0.25$, and $0.50 \mathrm{mg} / \mathrm{mL}$. tThe results wasare presented as percentage of superoxide radical-s scavenging activity. The letters (a) relative to Fig. 1A, \% of superoxide radical-s scavenging activity ofin the atemoya peel extracts, (b) relative to Fig. 1B, \% of superoxide radical-s scavenging activity ofin the atemoya pulp extracts

In the present study, the 1:1 pulp extract exhibited one of the highest superoxide radical-scavenging activities, followed by the 1:8 and 1:10 extracts, the latter two being the dilutions used in most of the households in the world for preparing juices [26]. Considering this fact, it is suggested that the fruit possesses a wide beneficial potential, which can be useful to several individuals. The use of the concentrations 1:8 and 1:10 in manufacturing fruit juices, especially that of atemoya, may promote its antioxidant activity and can lead to the prevention of several chronic diseases (Figure la and b) [27].

\section{Evaluation of Antioxidant Capacity by Iron Chelation}

The chelating capacity of a compound is defined by the formation of bonds between two or more separate binding sites within the same molecule and a central atom. This characteristic is generally attributed to organic compounds such as some types of proteins, carbohydrates, and phenolic compounds that bind to metal atoms, forming a chelate [28]. Figure 2 shows the results of the iron-chelating activity of the atemoya extracts. Since no chelating activity was detected for the pulp extracts, there are no data for these extracts in the figure. Regarding the iron-chelating activity, the highest activity was obtained with the 1:8 peel extract and the 1:4 seed extract. However, the activity of the seed extracts never exceeded that of the 1:8 peel extract. Evaluated the fruit parts (pericarp, pulp, and seeds) of soursop (A. muricata L.) using its aqueous extracts and showed that the pericarp extract showed the best results, followed by the pulp and seed extracts [29]. At the highest tested concentration of the atemoya seed extract, almost $60 \%$ chelation was achieved in the present study. The seed extract reached nearly $25 \%$. On the other hand, the soursop extracts at the same concentration exhibited a maximum metal (Fe) chelation activity of almost 40\% [29]. Thus, the atemoya fruit can be considered as a good metal (Fe) chelator compared with soursop. 
a)

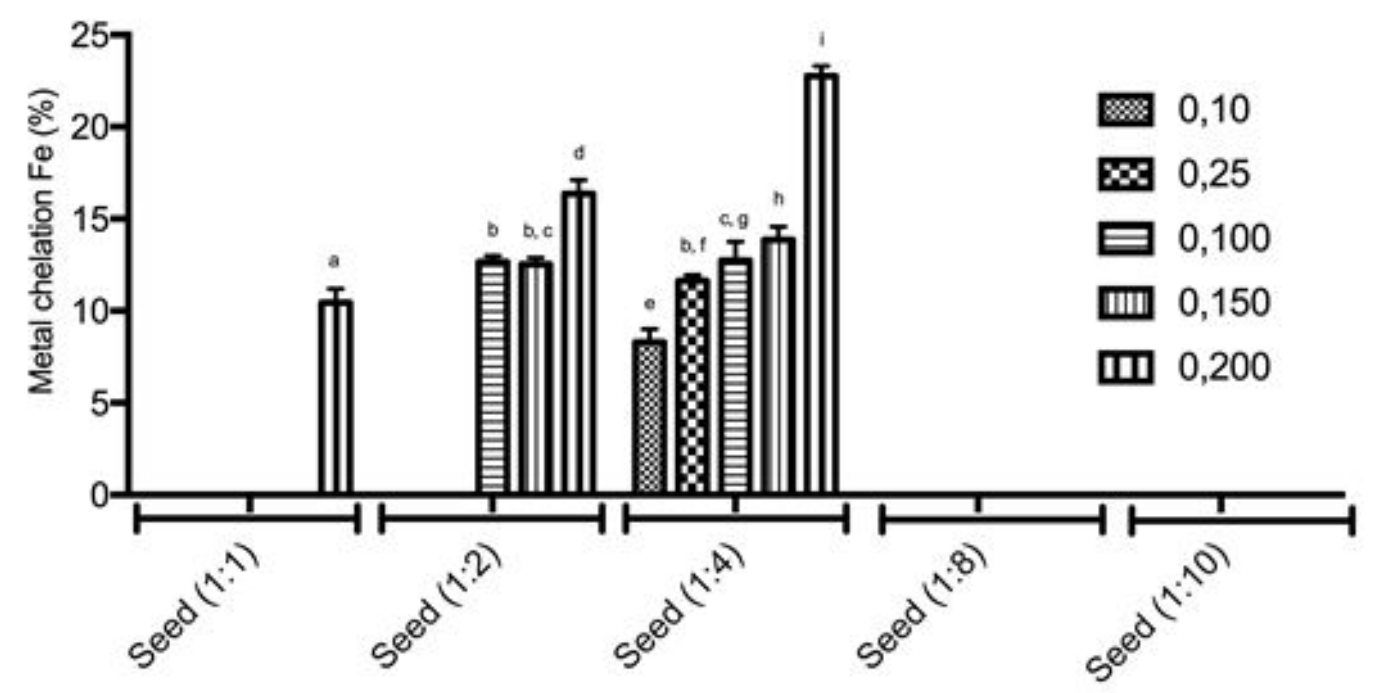

b)

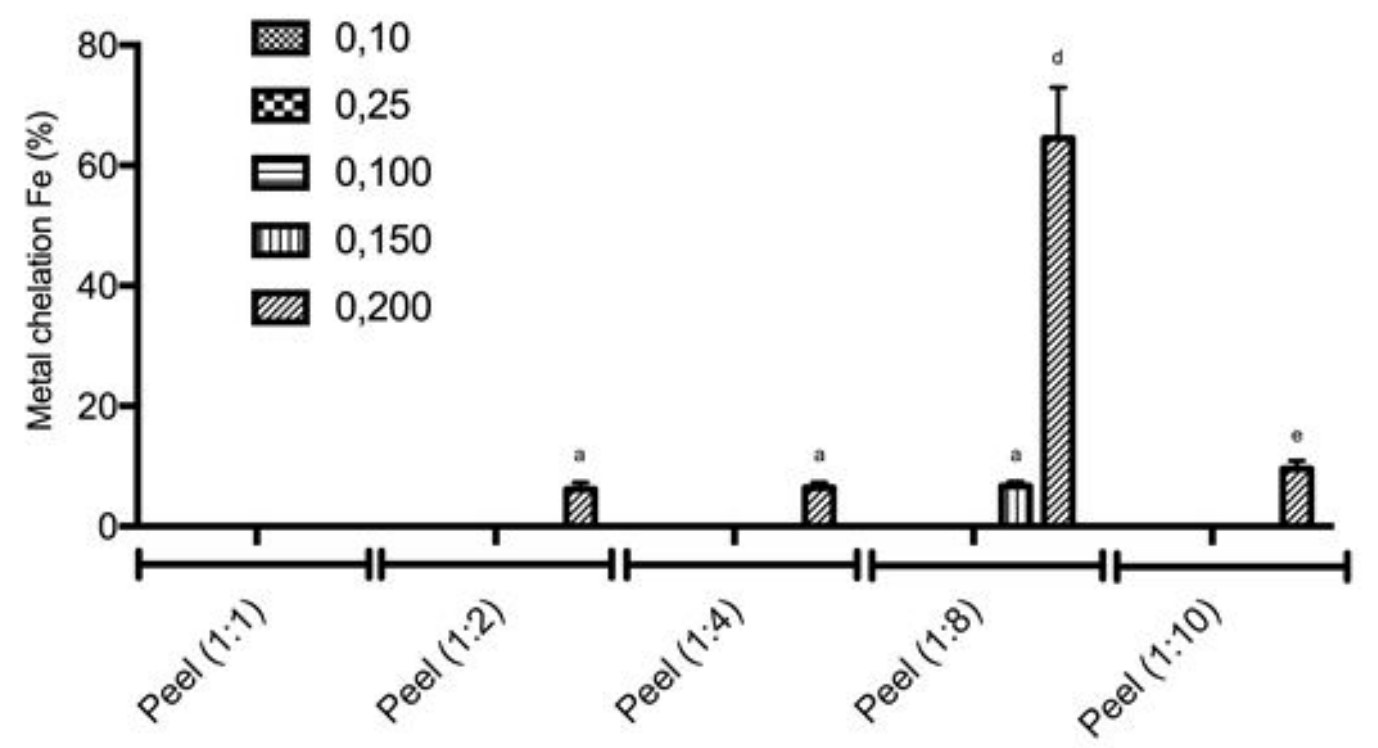

Figure 2: Metal antioxidant chelation capacity $(\mathrm{Fe})$. Results are presented as percentage of metal chelation (Fe). (a) Results of metal chelation for the seed extracts. (b) Results of metal chelation for the peel extracts

\section{Evaluation of Hydroxyl Radical-Scavenging Activity of Atemoya Extracts}

Figure 3 shows the results of the hydroxyl radical-scavenging activity of the atemoya fruit extracts (peel, pulp, and seed). All the extracts exhibited the activity at one of their respective concentration ratios $(1: 1,1: 2,1: 4,1: 8$, and 1:10). The seed extract showed activity only at the 1:1 concentration. The seed and pulp extracts exhibited the hydroxyl radical-scavenging activity at all the dilutions, with the 1:10 peel and the 1:1, 1:4, and 1:8 pulp extracts showing the maximum activity. conducted a study using cheese fruit (noni), papaya, and lemon showed that the extracts of these fruits exhibited an efficient hydroxyl radical-scavenging activity [30]. However, for achieving 50\% activity, the authors required 4.98, 3.6, and $6.92 \mathrm{mg} / \mathrm{mL}$ concentrations of the fruit extracts, respectively, which were higher than those used for the atemoya fruit extracts in the present study.

\section{Assessment of Correlation between the Extracts}

Identifying metabolites such as proteins, carbohydrates, and phenolic compounds in food is one of the great achievements of science because of the high possibility that they possess functional properties, among which the antioxidant activity is significant. Therefore, the correlation between the antioxidant activities and the metabolites was investigated in this study, as shown in Table 5 . 
a)

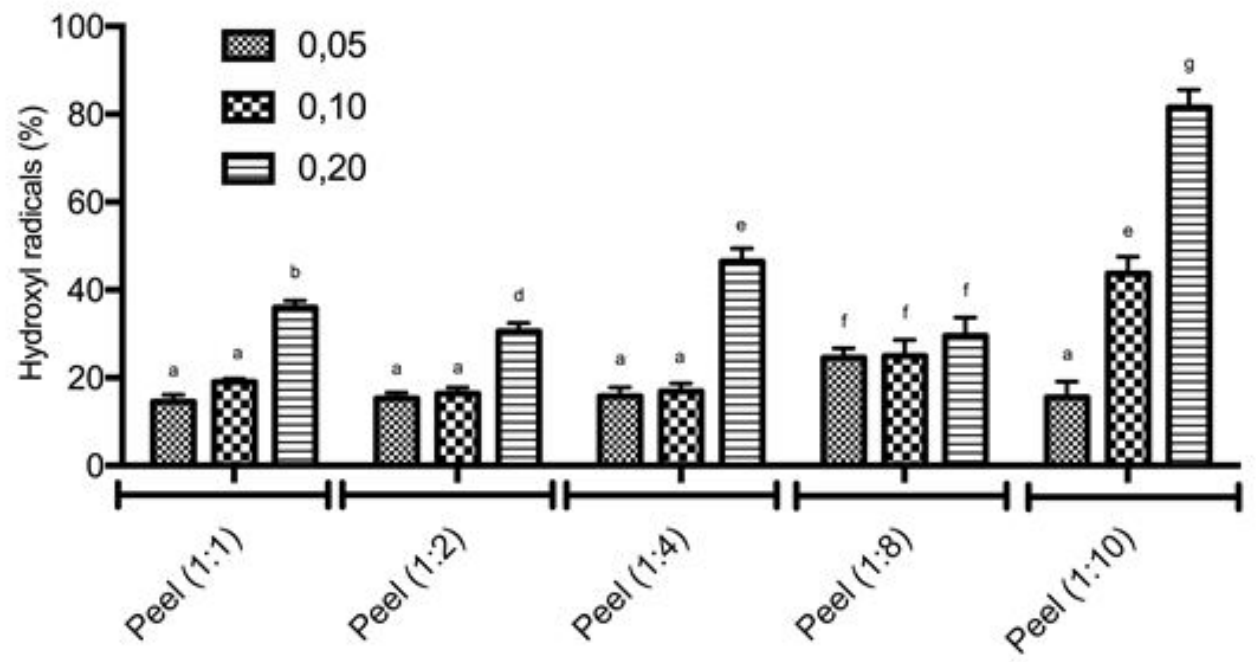

b)

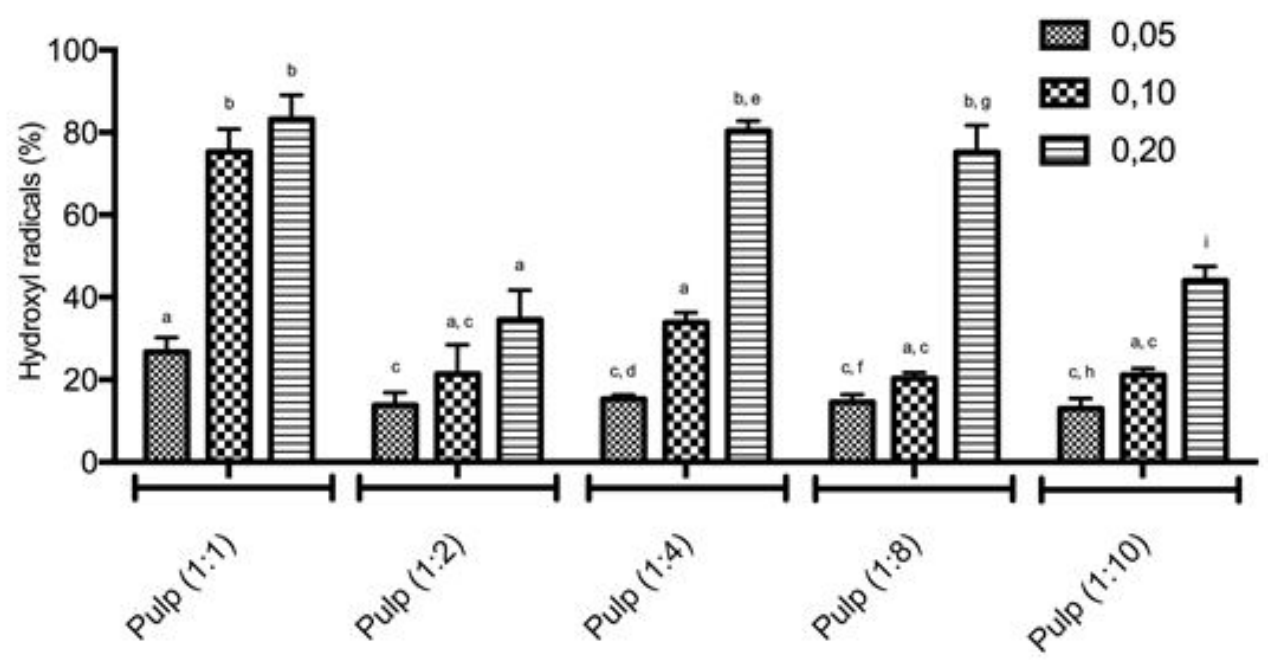

c)

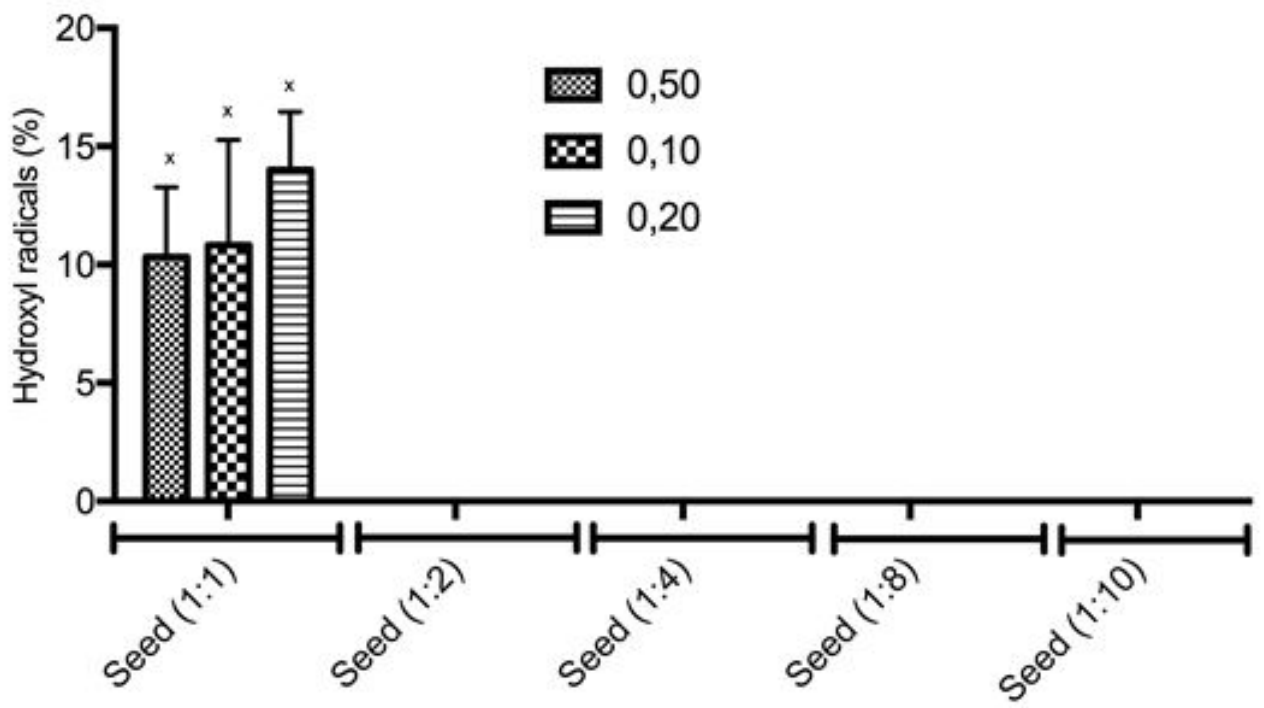

Figure 3: Hydroxyl radical-scavenging activity of the peel (a), pulp (b), and seed (c) extracts. The concentration unit of the samples is $\mathrm{mg} / \mathrm{mL}$ 


\begin{tabular}{|c|c|c|c|c|c|}
\hline \multicolumn{6}{|c|}{ Seed extract } \\
\hline & & TAC & SRS & MCA & HRS \\
\hline \multirow{2}{*}{ Proteins } & $\mathrm{CP}$ & $0,893^{* *}$ & $-0,67$ & 0,027 & $0,811^{\star *}$ \\
\hline & $P$ & 0,000 & 0,725 & 0,889 & 0,000 \\
\hline \multirow{2}{*}{ Carbohydrates } & $\mathrm{CP}$ & $-0,938^{\star *}$ & $-0,134$ & 0,350 & $-0,307$ \\
\hline & $P$ & 0,000 & 0,481 & 0,058 & 0,099 \\
\hline \multirow{2}{*}{$\begin{array}{l}\text { Phenolic } \\
\text { compounds }\end{array}$} & $\mathrm{CP}$ & $0,440^{*}$ & $-0,287$ & $-0,640^{* *}$ & $-0,300$ \\
\hline & $P$ & 0,015 & 0,124 & 0,000 & 0,876 \\
\hline \multicolumn{6}{|c|}{ Pulp extract } \\
\hline \multirow{2}{*}{ Proteins } & $\mathrm{CP}$ & $0,500^{* *}$ & 0,176 & a & 0,355 \\
\hline & $P$ & 0,044 & 0,351 & $\mathrm{a}$ & 0,054 \\
\hline \multirow{2}{*}{ Carbohydrates } & $\mathrm{CP}$ & $0,498^{* *}$ & 0,148 & $\mathrm{a}$ & $-0,262$ \\
\hline & $P$ & 0,005 & 0,436 & $\mathrm{a}$ & 0,162 \\
\hline \multirow{2}{*}{$\begin{array}{l}\text { Phenolic } \\
\text { compounds }\end{array}$} & $\mathrm{CP}$ & 0,200 & 0,140 & $\mathrm{a}$ & 0,210 \\
\hline & $P$ & 0,290 & 0,462 & $\mathrm{a}$ & 0,265 \\
\hline \multicolumn{6}{|c|}{ Peel extract } \\
\hline \multirow{2}{*}{ Proteins } & $\mathrm{CP}$ & $0,841^{* *}$ & $-0,558^{\star *}$ & $-0,125$ & $-0,609^{* *}$ \\
\hline & $P$ & 0,000 & 0,001 & 0,509 & 0,000 \\
\hline \multirow{2}{*}{ Carbohydrates } & $\mathrm{CP}$ & 0,022 & $-0,482^{\star *}$ & $-0,966^{* *}$ & 0,313 \\
\hline & $P$ & 0,909 & 0,007 & 0,000 & 0,092 \\
\hline \multirow{2}{*}{$\begin{array}{l}\text { Phenolic } \\
\text { compounds }\end{array}$} & $\mathrm{CP}$ & $-0,159$ & $-0,520^{* *}$ & $-0,19$ & $-0,460^{*}$ \\
\hline & $P$ & 0,400 & 0,003 & 0,314 & 0,010 \\
\hline
\end{tabular}

Table 5: Correlation between the antioxidant activity, proteins, carbohydrates, and phenolic compounds ${ }^{*}$ Significant correlation $<0.05$, and ${ }^{* *}$ significant correlation $<0.001$; a - showed no activity; TAC - total antioxidant capacity; SRS - superoxide radical-scavenging; MCA -metal-chelating activity (Fe); HRS hydroxyl radical-scavenging.

\section{Correlation between TAC, Soluble Proteins, Carbohydrates, and Phenolic Compounds}

After evaluating the TAC results to identify the primary components responsible for this activity, it was observed that proteins were the primary agents acting as electron donors in the TAC test. This could be due to the strong positive correlation of the proteins with the TAC, both for the seed (Pearson's correlation $=0.893 ; \mathrm{p}<0.01$ ) and for the peel (Pearson's correlation $=0.841 ; \mathrm{p}<$ 0.01 ) extracts. An intermediate positive correlation with the pulp extracts (Pearson's correlation $=0.500 ; \mathrm{p}<0.01$ ) was also found. Regarding the phenolic compounds, in both the pulp and the seed extracts, a low positive correlation was found between the TAC and this component. Only for the seed extracts, a correlation between TAC and phenolic compounds was identified, although it was only intermediate (Pearson's correlation $=0.440 ; \mathrm{p}<0.05$ ). These data were somewhat unexpected because most of the studies evaluating the antioxidant activity of fruit extracts have indicated phenolic compounds as the primary agents responsible for such activity [31]. In spite of that, in the vast majority of these studies, the activity of the extracts was not evaluated through the TAC test. This would explain this disparity and, on the other hand, would show why the data presented herein highlight the proteins of the extracts, a fact that has been rarely depicted in the literature. Regarding the carbohydrates, the results clearly showed that there are different types of these molecules in each of these extracts, since positive and intermediate correlations were identified with the peel and pulp extracts, respectively. On the other hand, for the seed extracts, this correlation was strongly negative (Pearson's correlation $=-0.936 ; \mathrm{p}<0.01)$.

\section{Correlation between the Superoxide Radical-Scavenging Activity, Soluble Proteins, Carbohydrates, and Phenolic Compounds}

In the superoxide radical-scavenging test, the peel extracts showed an intermediate correlation between protein, carbohydrates, and phenolic compounds (Pearson's correlation coefficients $=0.558, \mathrm{p}<0.01 ; 0.482, \mathrm{p}<0.01$; and 0.520 , $\mathrm{p}<0.01$, respectively). These results indicate the interaction between the compounds (protein, carbohydrates, and phenolic compounds), suggesting that the fluctuations in the activities of the peel extracts at the different concentrations are due to the different amounts of these substances. With the seed and pulp extracts, no significant correlations were found between superoxide ion-scavenging activity and proteins, carbohydrates, and phenolic compounds. The positive activities found in these extracts indicate the presence of other superoxide radical-scavenging substances in this part of the fruit. 


\section{Correlation between Hydroxyl Radical-Scavenging Activity, Soluble Proteins, Carbohydrates, and Phe- nolic Compounds}

Although the seed extract exhibited activity only at the 1:1 concentration, this result indicated a high correlation with the proteins (Pearson's correlation $=0.811 ; \mathrm{p}<0.01$ ). For the carbohydrate and phenolic compounds, no correlation was identified, which indicates that the only class of molecules studied herein responsible for the hydroxyl-scavenging activity of the seed extracts is the proteins. This would explain the lack of increased activity of the extract, given the increment in the amount of solvent, and that probably, when increasing the amount of solvent, the extraction of substances that would act inhibiting the action of the proteins is increased,inhibiting, thereby, the scavenging activity of the extracts, since it is dependent on proteins. With the pulp extracts, no correlation was found with protein, carbohydrate, and phenolic compounds. The Pearson's correlation was negative for protein and phenolic compounds (Pearson's correlation coefficients $=-0.609, \mathrm{p}<0.01$, and $-0.460, \mathrm{p}<0.05$, respectively). For carbohydrates, no correlation was found. However, the hydroxyl-scavenging activity was observed for these two extracts, which indicates the presence of other metabolites in these extracts involved in this test. These metabolites are not present in the seed extracts.

\section{Studying the Extract and the Ratios with the Best Indices among the Antioxidant Activity Tests}

Table 6 shows that the best activities were observed at 1:1 concentration for the seed, 1:1 concentration for the pulp, and 1:10 concentration for the peel, indicating that the potential action depends on the amount of solvent and proportion in the samples.

\begin{tabular}{|c|c|c|c|c|c|c|c|c|c|c|c|c|c|c|c|}
\hline & \multicolumn{5}{|c|}{ Seed } & \multicolumn{5}{|c|}{ Pulp } & \multicolumn{5}{|c|}{ Peel } \\
\hline & $1: 1$ & $1: 2$ & $1: 4$ & $1: 8$ & $1: 10$ & $1: 1$ & $1: 2$ & $1: 4$ & $1: 8$ & $1: 10$ & $1: 1$ & $1: 2$ & $1: 4$ & $1: 8$ & $1: 10$ \\
\hline TAC & 3 & 3 & 2 & 2 & 2 & 3 & 1 & 1 & 3 & 3 & 2 & 2 & 2 & 1 & 2 \\
\hline S & 0 & 0 & 0 & 0 & 2 & 3 & 3 & 3 & 2 & 3 & 1 & 1 & 2 & 3 & 3 \\
\hline IC & 2 & 2 & 3 & 0 & 0 & 0 & 0 & 0 & 0 & 0 & 0 & 1 & 1 & 3 & 2 \\
\hline HR & 1 & 0 & 0 & 0 & 0 & 3 & 2 & 3 & 3 & 2 & 2 & 2 & 3 & 2 & 3 \\
\hline Total & 6 & 5 & 5 & 2 & 4 & 9 & 6 & 7 & 8 & 8 & 5 & 6 & 8 & 9 & 10 \\
\hline
\end{tabular}

Table 6: Concentration score in the antioxidant test

Total antioxidant capacity - TAC $=0=0 ; 1-50=1 ; 50 \mathrm{t}^{\circ} 100=2$; over $100=3$. $\mathrm{S}=0=0 ; 1-20=1 ; 20-60=2$; over $60=3$. Metal chelation $(\mathrm{Fe})-\mathrm{IC}=0=0 ; 1-10=1 ; 10-20=2$; over $20=3$. Hydroxyl Radicals $-\mathrm{HR}=0=0 ; 1-10=1 ; 20-60=2 ;$ over $60=3$.

\section{Conclusion}

The use of different volumes of solvent for obtaining the extracts affects, but not in a directly proportional manner, the amount of molecules extracted, such as proteins, carbohydrates, and phenolic compounds, as well as others not identified herein. Therefore, this affects the antioxidant activities exhibited by the extracts. Thus, the best scavenging activities of superoxide and hydroxyl radicals were obtained with the pulp extracts, whereas the peel extracts yielded the best iron-chelating activity. However, in general, the extracts that showed the best antioxidant activities were the 1:1 seed, the 1:1 pulp, and the 1:10 peel. Among the components of the extracts, the proteins were significant, with a positive influence on the antioxidant activity of the extracts in different tests. This study has provided overall experimental evidence on atemoya (peel, seed, and pulp) as a potential source of antioxidant metabolites. As of now, in vivo studies are necessary to confirm the beneficial effects of the consumption of extracts from different parts of the fruit.

\section{Disclosure Statement}

No potential conflict of interest was reported by the authors.

\section{Acknowledgments}

The authors gratefully acknowledge the financial support of the CNPq (Conselho Nacional de Desenvolvimento Científico e Tecnológico) and CAPES (Coordenação de Aperfeiçoamento de Pesssoal de Nível Superior). Hugo Rocha is CNPq fellowship honored researcher. Marilia Negreiros receives a Ph.D scholarship from CAPES. This research was presented at Programa de PósGraduação em Ciências da Saúde at Universidade Federal do Rio Grande do Norte, as part of the Ph.D thesis of Alexandre Serquiz.

\section{Conflict of Interest}

The authors declare that they have no conflict of interest.

\section{References}

1. Sun T, Tanumihardjo SA (2007) An integrated approach to evaluate food antioxidant capacity. J Food Scie 72: 159-65.

2. Bravo L (1998) Polyphenols: chemistry, dietary sources, metabolism, and nutritional significance. Nutr Rev 56: $317-33$.

3. Sies H, Berndt C, Jones DP (2017) Oxidative stress. Annu Rev Biochem 86: 715-48. 
4. Halliwell B (2007) Biochemistry of oxidative stress. Biochem Soc Trans 35: 1147-50.

5. WHO (2006) Global Strategy on Diet, Physical Activity and Health: A framework to monitor and evaluate implementation, Geneva, Switzerland.

6. Goot AJ, Pelgrom PJ, Berghout JA, Marlies EJG, Lena J, et al. (2016) Concepts for further sustainable production of foods. J Food Eng 168: 42-51.

7. Bataglion GA, Da Silva FM, Eberlin MN (2015) Determination of the phenolic composition from Brazilian tropical fruits by UHPLC-MS/MS. Food Chem 180: 280-7.

8. O'shea N, Arendt EK, Gallagher E (2012) Dietary fibre and phytochemical characteristics of fruit and vegetable by-products and their recent applications as novel ingredients in food products. Innov Food Sci Emerg Tech 16: 1-10.

9. Almeida JRGS, Araújo ECDC, Ribeiro LADA, Julianeli TDL, Xirley PN, et al. (2012) Antinociceptive activity of ethanol extract from Duguetiachrysocarpa Maas (Annonaceae). Scientific Word J 2012: 1-6.

10. Sanitary Surveillance Agency (Brazil) (2004) Resolution RDC No 216, Technical Regulation of Good Practices for Food Services, Official Diary of the Union, Executive power, Brazil.

11. Melo-Silveira RF, Fidelis GP, Viana RL, Soeiro VC, Silva RA, et al. (2014) Antioxidant and Antiproliferative Activities of Methanolic Extract from a Neglected Agricultural Product: Corn Cobs Molecules 19: 5360-78.

12. Bradford MM (1976) A rapid and sensitive method for the quantitation of microgram quantities of protein utilizing the principle of protein-dye binding. Anal Biochem 72: 248-54.

13. Dubois M, Gilles KA, Hamilton JK, PA Rebers, F Smith, et al. (1956) Colorimetric method for determination of sugars and related substances. Anal Chem 28: 350-6.

14. Galinari É, Sabry DA, Sassaki GL, Gorete RM, Flávia MLP, et al. (2016) Chemical structure, antiproliferative and antioxidant activities of a cell wall $\alpha$-d-mannan from yeast Kluyveromycesmarxianus. CarbohydrPolym 157: 1298-305.

15. Klein AM, Vaissiere BE, Cane JH, Ingolf SD, Saul AC, et al. (2007) Importance of pollinators in changing landscapes for world crops. Proc Biol Sci 274 : 303-13. 16. Lin JY, Tang CY (2007) Determination of total phenolic and flavonoid contents in selected fruits and vegetables, as well as their stimulatory effects on mouse splenocyte proliferation. Food Chem 101: 140-7.

17. Haminiuk CWI, Maciel GM, Oviedo MSVP, Peralta RM (2012) Phenolic compounds in fruits-an overview. Int J Food Sci Tech 47: 2023-44.

18. Alves MGCF, J Almeida L, AAO Paiva, Edda LL, HAO Rocha, et al. (2015) Extraction process optimization of sulfated galactan-rich fractions from Hypneamusciformis in order to obtain antioxidant, anticoagulant, or immunomodulatory polysaccharides. J Appl Phycol 28: 1931-42.

19. Pereira AC, Wurlitzer NJ, Dionisio AP, Lacerda SMV, Rocha BMDS, et al. (2015) Synergistic, additive and antagonistic effects of fruit mixtures on total antioxidant capacities and bioactive compounds in tropical fruit juices. Arch Latinoam Nutr 65: 19-27.

20. Barros, Joanna DADC (2012) Avaliação da atividade antioxidante e antiproliferativa do extrato aquoso de frutas tropicais. Dissertação, Universidade Federal do Rio Grande do Norte.

21. Sahreen S, Khan MR, Khan RA (2010) Evaluation of antioxidant activities of various solvent extracts of Carissa opaca fruits. Food Chem 122: 1205-11.

22. Li XM, Li XL, Zhou AG (2007) Evaluation of antioxidant activity of the polysaccharides extracted from Lyciumbarbarum fruits in vitro. Eur Polym J 43: 488-97.

23. Tang Y, Li X, Chen PX, Zhang B, Hernandez M, et al. (2015) Characterisation of fatty acid, carotenoid, tocopherol/tocotrienol compositions and antioxidant activities in seeds of three Chenopodium quinoa Willd. Genotypes Food Chem 174: 502-8.

24. Juliana I, Rosalen PL, Lazarini JG, M Franchin, SM Alenca, et al. (2016) Antioxidant and Anti-Inflammatory Activities of Unexplored Brazilian Native Fruits. PloS one 11: 1-3.

25. Krishnasamy G, Muthusamy K (2015) In vitro evaluation of antioxidant and antidiabetic activities of Syzygiumdensiflorum fruits. Asian Pac J Trop Dis 5: 912-7.

26. Araujo MOD, Guerra TMM (2007) Alimentos per capita, $3^{\text {a }}$ rdedn. UFRN, Brazil.

27. Chang SK, Alasalvar C, Shahidi F (2016) Review of dried fruits: Phytochemicals, antioxidant efficacies, and health benefits. J Func Foods 21: 113-32.

28. Athukorala Y, Kim KN, Jeon YJ (2006) Antiproliferativeande antioxidant propertis of an enzymatic hydrolysate from brown alga, Ecklonia cava. Food Chem Toxicol 44: 1065-74.

29. Adefegha AS, Oyeleye SI, Oboh G (2015) Distribution of Phenolic Contents, Antidiabetic Potentials, Antihypertensive Properties, and Antioxidative Effects of Soursop (Annonamuricata L) Fruit Parts In Vitro. Biochem Res Int 2015: 1-8.

30. Gironés VA, Valentão P, Andrade PB, Ferreres F, Moreno DA, et al. (2015) Beverages of lemon juice and exotic noni and papaya with potential for anticholinergic effects. Food Chem 170: 16-21.

31. Khang T, Dung TN, Elzaawely AA (2016) Phenolic Profiles and Antioxidant Activity of Germinated Legumes. 


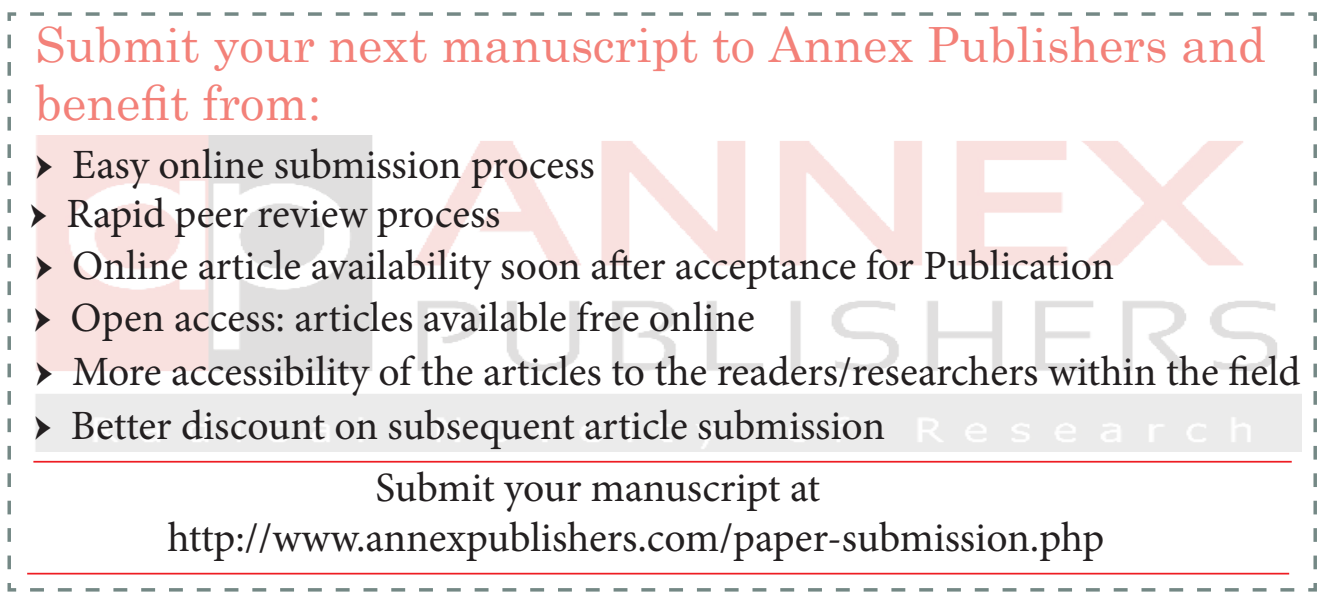

